\title{
OPTIMASI FORMULASI SABUN MANDI CAIR EKSTRAK ETANOL RIMPANG JAHE MERAH (Zingiber officinale Rosc. var rubrum) DENGAN METODE SIMPLEX LATTICE DESIGN
}

\author{
Randi Mulyana Putra, Andhi Fahrurroji, dan Bambang Wijianto \\ Program Studi Farmasi Fakultas Kedokteran \\ Universitas Tanjungpura Pontianak \\ Email: randi_apt@yahoo.com
}

\begin{abstract}
Prevention of diseases caused by bacteria can be carried out with the use of antibacterial soap. The use of antibacterial soaps derived from natural one is to plant a red ginger (Zingiber officinale Rosc. var rubrum) which proved to have antibacterial activity. Therefore, preparations to make it more acceptable liquid soap containing antibacterial compounds 6-shogaol, gingerol, and zingiberen from red ginger plant. Simplex Lattice Design is a method which to find a good formula of dosage from. The study aims to determine the optimum formulation liquid soap ethanolic extract of red ginger rhizome using the method of Simplex Lattice Design. Simplex Lattice Design Methods used to optimize the formulation of liquid soap with five formulas with variations in the amount of olive oil and potassium hydroxide (KOH), FI (0\%:100\%), FII (25\%:75\%), FIII (50\%:50\%), FIV (75\%:25\%), FV (100\%:0\%). Evaluation of liquid soap ethanol extract of red ginger rhizome (Zingiber officinale Rosc. var rubrum) include an examination viscosity, $p H$, and free alkali. Physical stability was analized to find higher total response value ( $R$ total) as parameter of the optimum formula by Simplex Lattice Design Methods with Design Expert software version 8.0.7.1. Optimum formula liquid soap ethanolic extract of red ginger rhizome with the proportion of variation base olive oil $98,1 \%(27,167 \mathrm{~g})$ and potassium hydroxide $(\mathrm{KOH})$ 1,9\% (3,99 g). Data obtained physical characteristics test compared with prediction value using Design Expert software version 8.0.7.1. The result showed that physical properties of liquid soap formula optimum didn't different significantly for easy response.
\end{abstract}

Keyword: Liquid Soap; Olive Oil; Potassium Hydroxide; Simplex Lattice Design.

\begin{abstract}
ABSTRAK
Pencegahan terhadap penyakit yang disebabkan oleh bakteri dapat dilakukan dengan penggunaan sabun mandi. Penggunaan sabun mandi yang berasal dari alam, salah satunya adalah dengan tanaman jahe merah (Zingiber officinale Rosc. var rubrum) yang terbukti memiliki aktivitas antibakteri. Oleh karena itu supaya lebih acceptable dibuat sediaan sabun mandi cair yang mengandung senyawa antibakteri 6-shogaol, gingerol dan zingiberen dari tanaman jahe merah. Simplex Lattice Design merupakan metode yang digunakan untuk mendapatkan formula terbaik secara cepat. Penelitian ini bertujuan untuk mengetahui formula optimum sabun mandi cair ekstrak etanol rimpang jahe merah menggunakan metode Simplex Lattice Design. Metode Simplex Lattice Design digunakan untuk optimasi formula sabun mandi cair dengan lima formula berdasarkan variasi jumlah basis minyak zaitun dan kalium hidroksida (KOH), FI (0\%:100\%), FII (25\%:75\%), FIII (50\%:50\%), FIV (75\%:25\%), FV (100\%:0\%). Evaluasi sabun cair ekstrak etanol rimpang jahe merah meliputi pemeriksaan viskositas, uji $\mathrm{pH}$, dan uji alkali bebas. Sifat fisik sabun mandi cair optimum diuji dengan uji T-test One Sampel dengan sifat fisik formula optimum prediksi metode Simplex Lattice Design dengan software Design Expert versi 8.0.7.1. Formula optimum sabun mandi cair diperoleh dengan variasi jumlah basis minyak zaitun $98,1 \%(27,167 \mathrm{~g})$ dan kalium hidroksida $(\mathrm{KOH}) 1,9 \%(3,99 \mathrm{~g})$. Hasil evaluasi sabun mandi cair optimum menunjukkan nilai rata-rata viskositas 5 Poise $(\mathrm{P})$, alkali bebas 2,2\%, dan $\mathrm{pH}$ 9,233 . Formula optimum yang diperoleh mempunyai respon viskositas, $\mathrm{pH}$, dan alkali bebas yang tidak berbeda signifikan dengan prediksi respon yang dihasilkan oleh software Design Expert versi 8.0.7.1.
\end{abstract}

Kata Kunci: Kalium Hidroksida; Minyak Zaitun; Sabun Mandi Cair; Simplex Lattice Design. 


\section{PENGANTAR}

Perilaku kebersihan yang tidak baik akan mempermudah tubuh untuk terserang berbagai penyakit seperti penyakit kulit. Jumlah penduduk di Indonesia yang terinfeksi penyakit kulit sebanyak 501.280 jiwa atau 3,16\%, Penyakit tersebut dapat disebabkan oleh adanya bakteri patogen di tubuh (DepKes RI, 2006; DepKes RI, 2013).

Pencegahan terhadap penyakit yang disebabkan oleh bakteri dapat dilakukan dengan penggunaan sabun mandi antibakteri. Sediaan sabun mandi antibakteri yang banyak beredar di pasaran mengandung bahan sintetik seperti SLS (Sodium Lauryl Sulfat) dan Tryclosan. Penggunaan melebihi konsentrasi yang dianjurkan akan bersifat karsinogenik dan dapat menyebabkan terjadinya iritasi epidermis serta denaturasi rantai polipeptida suatu molekul protein sehingga merubah struktur protein (Roslan, dkk, 2009).

Penggunaan produk berbahan baku alam mulai dinimati masyarakat Indonesia, karena tingkat keamanannya yang baik. Jahe Merah (Zingiber officinale Rosc. var rubrum) merupakan tanaman yang telah banyak diteliti memiliki aktivitas antibakteri. Kandungan senyawa yang terdapat pada jahe merah dapat memberikan aktivitas antibakteri di antaranya fenol, flavonoid, minyak atsiri, tannin, dan terpenoid. Senyawa murni yang memiliki aktivitas antibakteri dari rimpang jahe (Zingiber officinale) hasil isolasi dengan fraksi metanol adalah senyawa golongan fenolik yaitu 6-shogaol, gingerol, dan zingiberen (Rahmawati, dkk, 2012)

Sediaan sabun mandi yang beredar di pasaran antara lain dalam bentuk cair dan batang. Sabun mandi cair memiliki kelebihan antara lain proses pembuatannya relatif lebih mudah, biaya produksinya yang murah, serta mudah penyimpanan dan penggunaannya sehingga, sabun tidak mudah rusak (DepKes RI, 1996). Penggunaan basis dari sabun mandi cair dapat mempengaruhi efektivitas dari sabun mandi tersebut. Basis sabun mandi cair yang memberikan hasil baik yaitu minyak zaitun dan kalium hidroksida $(\mathrm{KOH})$ karena memberikan efek mengurangi kulit yang kering setelah 35 hari pemakaian dan tidak menimbulkan iritasi pada kulit, baik iritasi primer maupun iritasi sekunder (Anggraini, dkk, 2009).

\section{Metode}

Alat yang digunakan adalah autoklaf, alkoholmeter, blender (Cosmos 289-G), cawan penguap, cawan petri, corong gelas, gelas beaker (Iwaki Pyrex), gelas erlenmeyer (Iwaki Pyrex), gelas ukur (Iwaki Pyrex), hot plate (Thermolyne Hot Plate RC 2240), kaca arloji, lemari oven (Memmert Beschickung-Loading Model 100-800), perkolator, jarum ose, desikator, rotary evaporator (Rotavapor II BUCHI), viskometer stomer, $\mathrm{pH}$ meter, dan timbangan analitik (Precisa tipe XB 4200C dan BEL tipe M254Ai).

Bahan-bahan yang digunakan adalah tanaman jahe merah, aquadest, asam oleat, asam stearat, alumunium foil, asam sulfat pekat, asam asetat glasial, Etanol 96\% teknis, $\mathrm{FeCl} 1 \%$, indikator phenolptalein, serbuk $\mathrm{Mg}$, $\mathrm{H} 2 \mathrm{SO} 4$ pekat, $\mathrm{FeCl} 5 \%$, larutan $\mathrm{HCl}$ pekat, $\mathrm{HCl}$ $0,1 \mathrm{~N}$, larutan $\mathrm{NaCl}, \mathrm{NaCl}$ steril $0,9 \%$, pereaksi Molisch, kloroform, tissue, plastik tahan panas (Wayang), plastik wrapping, pereaksi Mayer, pereaksi Dragendroff, Minyak Zaitun, Gliserin, $\mathrm{KOH}$, kertas saring, Butil Hydroksida Toluent (BHT), Media Mueller-Hinton Agar (MHA), dan Media Nutrient Agar (NA).

Tanaman jahe merah (Zingiber officinale Rosc. var rubrum) dideterminasi bagian rimpangnya dengan mencocokkan ciri-ciri morfologinya, dan dilakukan di Laboratorium Pusat Lembaga Ilmu Pengetahuan Biologi LIPI Bidang Botani. Sampel yang digunakan berupa bagian rimpang tanaman jahe merah (Zingiber officinale Rosc. var rubrum). Rimpang jahe merah dipilih ketika masih segar.Rimpang jahe merah dicuci selanjutnya dikeringkan di dalam oven dengan suhu 40-500C. Simplisia yang sudah kering kemudian diserbuk dan dilakukan proses ekstraksi. Ekstrak kental rimpang jahe merah dibuat dengan sokletasi dengan pelarut etanol 96\% teknis setiap 20-40 g dalam $150 \mathrm{~mL}$ pelarut etanol 96\% teknis (Poeloengan, 2011).

\section{Pembuatan Formula Sabun Mandi Cair}

Rancangan formula sabun mandi cair yang digunakan dalam penelitian ini terdiri dari lima formula, dapat dilihat pada tabel 1. 
RANDI MULYANA PUTRA, ANDHI FAHRURROJI, DAN BAMBANG WIJIANTO OPTIMASI FORMULASI SABUN MANDI CAIR EKSTRAK ETANOL RIMPANG JAHE MERAH (Zingiber officinale Rosc. var rubrum) ...

Tabel 1. Formula Sabun Mandi Cair

\begin{tabular}{llllll}
\hline \multirow{2}{*}{ Bahan } & \multicolumn{5}{c}{ Formula } \\
\cline { 2 - 6 } & \multicolumn{1}{c}{ I } & II & III & IV & V \\
\hline Ekstrak Jahe merah & $5 \mathrm{mg} / \mathrm{mL}$ & & & & \\
\hline Minyak Zaitun & $23,8 \mathrm{~g}$ & $20.3 \mathrm{~g}$ & $25,55 \mathrm{~g}$ & $22,05 \mathrm{~g}$ & $27,3 \mathrm{~g}$ \\
\hline Kalium Hidroksid & $7.35 \mathrm{~g}$ & $10,85 \mathrm{~g}$ & $5,6 \mathrm{~g}$ & $9,1 \mathrm{~g}$ & $3,85 \mathrm{~g}$ \\
\hline Asam Stearat & $0,25 \mathrm{~g}$ & & & & \\
\hline Asam Oleat & $2,5 \mathrm{~g}$ & & & & \\
\hline Gliserin & $2 \mathrm{~g}$ & & & & \\
\hline BHT & $0,1 \mathrm{~g}$ & & & & \\
\hline Aquadest & $100 \mathrm{~mL}$ & & & & \\
\hline
\end{tabular}

Optimasi formula sabun mandi cair ekstrak etanol rimpang jahe merah dilakukan menggunakan metode Simplex Lattice Design untuk dua variabel bebas (campuran dua komponen), maka dibuat lima formula pada berbagai komposisi campuran kedua komponen yang akan dioptimasi yaitu minyak zaitun dan kalium hidroksidan $(\mathrm{KOH})$.

\section{Uji Sifat Fisik Sabun Mandi Cair}

Sifat fisik sabun mandi cair yang diuji adalah viskositas, $\mathrm{pH}$, dan alkali bebas.

\section{Uji Viskositas}

Sampel yang diuji ditempatkan dalam wadah penampung bahan, wadah diatur ketinggiannya sehingga rotor dapat bergerak. Dicari rotor yang sesuai dengan tingkat kekentalan pada sampel, yaitu rotor no 1:0,3$15 \mathrm{P}$ (Poise), rotor no 2 : 3-150 P (Poise), dan rotor no 3:100-4000 P (Poise). Kemudian rotor ditempatkan pada penggantung dan diatur, sehingga diperoleh nilai viskositas pada sampel. Pengukuran viskositas dilakukan sebanyak tiga kali replikasi (SNI, 1996).

\section{Uji pH}

Pemeriksaan $\mathrm{pH}$ diawali dengan kalibrasi alat $\mathrm{pH}$ meter menggunakan larutan dapar $\mathrm{pH} 7$ dan $\mathrm{pH}$ 4. Satu gram sediaan yang akan diperiksa diencerkan dengan air suling hingga $10 \mathrm{~mL}$. Diambil sedikit sediaan dan ditempatkan pada tempat sampel $\mathrm{pH}$ meter, kemudian ditunggu hingga indikator $\mathrm{pH}$ meter stabil dan menunjukkan nilai $\mathrm{pH}$ yang konstan. Pemeriksaan $\mathrm{pH}$ dilakukan sebanyak tiga kali replikasi (SNI,1996).

\section{Uji Alkali Bebas}

Sebanyak $5 \mathrm{~g}$ sabun mandi cair ditimbang, dimasukkan ke dalam erlenmeyer $250 \mathrm{~mL}$. Ditambahkan $100 \mathrm{~mL}$ alkohol 96\% teknis dan beberapa tetes larutan indikator phenolptalein. Dipanaskan diatas penangas air memakai pendingin tegak selama 30 menit mendidih. Bila larutan berwarna merah, kemudian dititer dengan larutan $\mathrm{HCl} 0.1 \mathrm{~N}$ dalam alkohol sampai warna merah tepat hilang (SNI,1996)

\section{Kadar alkali bebas $=$}

Keterangan : $\frac{\mathrm{V} \times \mathrm{N} \times 56,1}{\mathrm{~W}} \times 100 \%$

$\mathrm{V} \quad=$ volume $\mathrm{HCl}$ yang digunakan untuk titrasi $(\mathrm{mL})$

$\mathrm{N}=$ Normalitas $\mathrm{HCl}$

$\mathrm{W}=$ Bobot sabun cair $(\mathrm{g})$

$56,1=$ bobot setara $\mathrm{KOH}$

\section{HASIL DAN PEMBAHASAN}

Hasil determinasi menunjukkan bahwa tanaman yang digunakan dalam penelitian ini adalah tanaman jahe merah (Zingiber officinale Rosc. var rubrum). Rendemen ekstrak yang dihasilkan yaitu sebesar 17,22318\%. Dengan persentase susut pengeringan ekstrak etanol rimpang jahe merah rata-rata dari tiga kali pengulangan adalah 30,7078\% dan jumlah kadar sari yang larut etanol rata-rata dari tiga kali pengulangan adalah $80,6166 \%$. 


\section{Pengujian Sifat Fisokimia Formula Simplex Lattice Design}

\section{Uji Viskositas Sabun Mandi Cair Simplex Lattice Design}

Analisis viskositas sabun mandi cair pada penelitian ini menggunakan rotary no 3 dengan nilai poise 0,3-15 Poise $(\mathrm{P})$, dan no 1 dengan nilai poise 3-150 Poise (P). Data pengaruh variasi basis minyak zaitun dan $\mathrm{KOH}$ terhadap viskositas dapat dilihat pada gambar 1 .

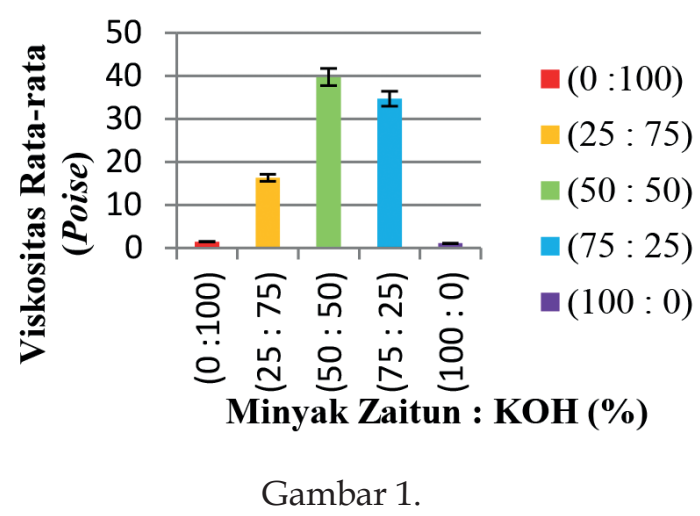

Pengaruh Variasi Basis Minyak Zaitun dan $\mathrm{KOH}$ terhadap Viskositas Produk

Sabun Mandi Cair

Dari hasil pengujian fomula III (50:50) memiliki nilai viskositas tertinggi. Hal ini dikarenakan bahwa, pada formula tersebut proses saponifikasi berjalan sempurna karena komposisi antara minyak zaitun dan basa $\mathrm{KOH}$ seimbang, jadi antara minyak dan $\mathrm{KOH}$ tersaponifikasi seluruhnya. Semakin seimbangnya komposisi antara asam lemak dan basa maka proses saponifikasi berjalan sempurna, sehingga semakin kental produk sabun yang dihasilkan. Selain itu juga, faktor lain yang mengakibatkan viskositas semakin besar yaitu lamanya pengadukan pada formula sabun mandi cair dan suhu yang digunakan dalam proses pembuatan formula sabun mandi cair.

\section{Uji pH Formula Sabun Mandi Cair Simplex Lattice Design}

Formula V (100:0) yang mengandung $0 \% \mathrm{KOH}$ memiliki $\mathrm{pH}$ yang lebih rendah dari formula lainnya. Sedangkan formula I (0:100) yang mengandung $100 \% \mathrm{KOH}$ memiliki $\mathrm{pH}$ lebih tinggi. Dari kelima formula yang menghasilkan sabun mandi cair dengan $\mathrm{pH}$ yang sesuai dengan batas yang berlaku adalah formula IV dan V. Hubungan antara variasi basis minyak zaitun dan $\mathrm{KOH}$ dengan $\mathrm{pH}$ sediaan dapat dilihat pada gambar 2 .

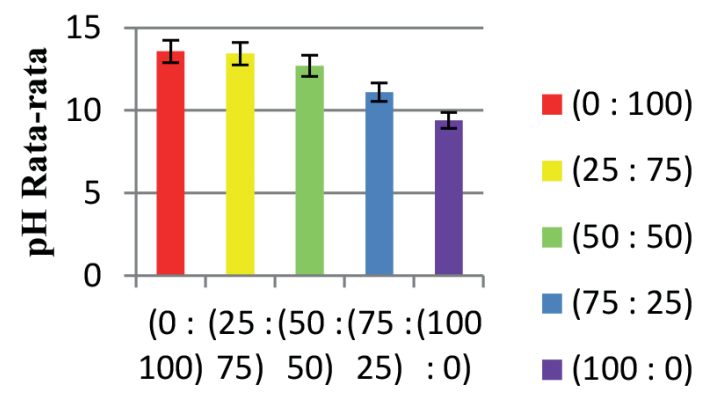

Minyak : Zaitun : KOH (\%)

Gambar 2.

Pengaruh Variasi Basis Minyak Zaitun dan $\mathrm{KOH}$ terhadap $\mathrm{pH}$

Perubahan $\mathrm{pH}$ pada sediaan dipengaruhi oleh variasi basis asam lemak dan basa yang digunakan pada sediaan sabun mandi cair serta bahan penyusun lainnya. Gambar 2., menunjukkan semakin banyak penambahan maupun pengurangan variasi basis baik minyak zaitun dan $\mathrm{KOH}$ dapat mempengaruhi $\mathrm{pH}$ pada suatu sediaan. Penurunan nilai $\mathrm{pH}$ juga diakibatkan adanya asam oleat, gliserin, dan asam stearat yang relatif asam $(\mathrm{pH}<5)$ (Rowe, dkk, 2006).

\section{Uji Alkali Bebas Sabun Mandi Cair Simplex Lattice Design}

Berdasarkan hasil pengamatan yang dilakukan maka diketahui nahwa kadar alkali bebas yang dikandung pada sabun memiliki kadar yang berbeda berkisar 1,9-22,90 \%. Hal ini membuktikan bahwa sabun mandi cair yang dihasilkan mengandung alkali bebas. Pengaruh hubungan variasi basis minyak zaitun dan $\mathrm{KOH}$ terhadap alkali bebas dapat dilihat pada gambar 3 . 


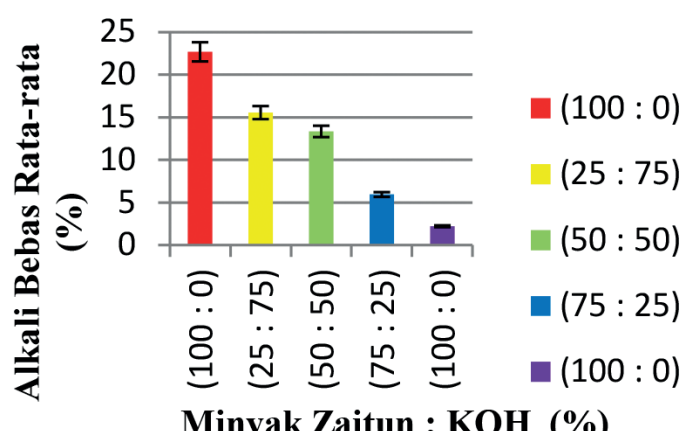

Gambar 3.

Hubungan Variasi Basis Minyak Zaitun dan $\mathrm{KOH}$ terhadap Kadar Alkali Bebas Gambar 3 ini menunjukan bahwa perubahan variasi basis minyak zaitun dan $\mathrm{KOH}$ memberikan pengaruh terhadap kadar alkali bebas. Semakin banyak basa alkali $(\mathrm{KOH})$ yang terkandung dalam sediaan, kadar alkali bebas semakin besar. Hal ini dikarenakan banyak basa alkali seluruhnya tidak tersaponifikasi sehingga banyak basa alkali yang bebas.

\section{Penentuan Formula Optimum Sabun Mandi Cair dengan Metode Simplex Lattice Design menggunakan software Design Expert versi berdasarkan respon fisik}

Data hasil pengujian sifat fisik dan kimia dimasukkan dan diolah dengan menggunakan program Design Expert 8.0.7.1 Trial. Program kemudian akan memprediksi formula optimum yang merupakan solusi dari setiap respon yang telah diatur dan ingin dicapai. Formula optimum hasil rediksi terdiri dari 98,1\% minyak zaitun dan 1,9\% $\mathrm{KOH}$ dengan nilai desirability sebesar 0.989 . Hal ini berarti formula yang diprediksi tersebut dapat menghasilkan sabun mandi cair dengan perkiraan viskositas sebesar 5,00001 Poise (P), pH sebesar 9,52594, dan kadar alkali bebas sebesar 2,22663\%. Nilai desirability merupakan nilai target optimasi yang dicapai, yang dinyatakan dalam rentang 0-1. Gambar kurva desirability dapat dilihat pada gambar 4 .

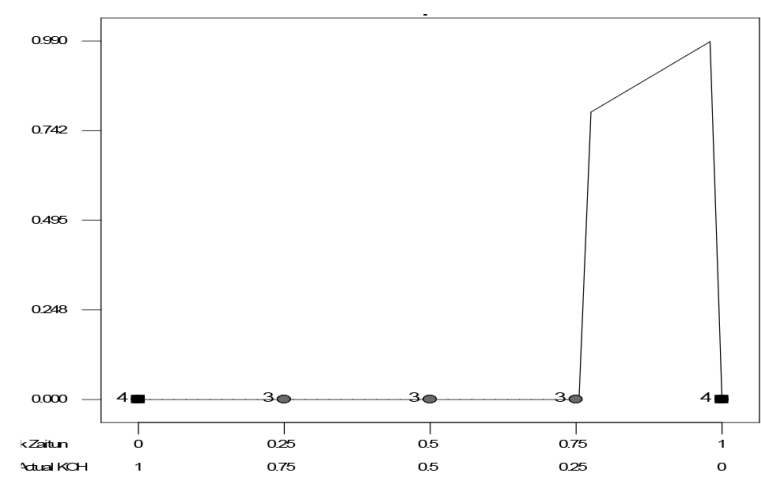

Variasi Basis Minyak Zaitun dan $\mathrm{KOH}$

Gambar 4. Kurva Desirability Formula Optimum

Gambar 4. menunjukkan kecenderungan nilai desirability apabila terdiri dari komponen A dan B dalam jumlah tertentu. Titik pada kurva menunjukkan bahwa kurva memiliki nilai koefisien korelasi yang cukup tinggi sehingga persamaan matematis yang diperoleh memberikan interaksi yang cukup tinggi sehingga dapat diperoleh formula optimum dengan sifat fisik dan kimia yang baik.

\section{Pengujian Sifat Fisik dan Kimia Formula Optimum}

Hasil uji organoleptik sediaan berwarna coklat, berbau khas jahe merah, dan konsistensi sediaan tidak terlalu kaku (+++). Hasil pengujian sifat fisik dan kimia optimum dapat dilihat pada tabel 2 .

Tabel 2.

Hasil Pengujian Sifat Fisik dan Kimia

Formula Optimum ( $n=3$, Respon \pm SD)

\begin{tabular}{l|llll}
\hline & Respon & $\begin{array}{c}\text { Hasil } \\
\text { Prediksi }\end{array}$ & Hasil Uji & $\begin{array}{c}\text { Nilai } \\
\text { Signifikansi }\end{array}$ \\
\cline { 2 - 5 } & Visko- & 5,00001 & $5 \pm$ & $\mathrm{p}>0,05$ \\
& Sitas & & 0,08165 & \\
\cline { 2 - 5 } & $\mathrm{pH}$ & 9,52594 & $9,233 \pm$ & $\mathrm{p}>0,05$ \\
& & 0,20548 & \\
\cline { 2 - 5 } & & & $0,2 \pm$ & $\mathrm{p}>0,05$ \\
& Alkali & 2,22663 & $2,2 \pm$ & \\
\hline
\end{tabular}

Keterangan: $\mathrm{n}$ : jumlah sampel, rata-rata, SD : standar deviasi 
Hasil analisis memperlihatkan formula optimum yang diperoleh mempunyai respon viskositas, $\mathrm{pH}$, dan alkali bebas yang tidak berbeda signifikan dengan prediksi respon yang dihasilkan oleh software Design Expert versi 8.0.7.1.

\section{SIMPULAN}

Hasil penelitian menunjukkan formula optimum sabun mandi cair ekstrak etanol rimpang jahe merah yang mengandung senyawa antibakteri 6-shogaol, zingiberen, dan gingerol diperoleh pada proporsi variasi basis minyak zaitun 98,1\% dan $\mathrm{KOH} \mathrm{9,1 \% .} \mathrm{Formula}$ optimum yang diperoleh mempunyai respon viskositas, $\mathrm{pH}$, dan alkali bebas yang tidak berbeda siginifikan dengan prediksi respon yang diberikan oleh software Design Expert versi 8.0.7.1. Sabun mandi cair yang diperoleh dengan esktrak etanol rimpang jahe merah memiliki sifat fisik yang baik ditinjau dari hasil respon viskositas, $\mathrm{pH}$, dan alkali bebas yang dihasilkan masuk ke dalam kriteria produk sabun mandi cair yang telah ditetapkan oleh SNI.

\section{UCAPAN TERIMA KASIH}

Terima kasih penyusun ucapkan kepada, kedua dosen pembimbing, dosen penguji, serta pihak yang terkait lainnya yang telah mendukung proses penelitian ini sehingga dapat terselesaikan dengan lancer.

\section{DAFTAR PUSTAKA}

Anggraini I, Boesro S, dan Sriwidodo. Formulasi Sabun Mandi Cair dengan Lendir Daun Lidah Buaya (Aloe vera Linn.). Skripsi. 2009; 1-4.

Departemen Kesehatan RI. Clinical Pathway di Rumah Sakit : Penyakit Kulit dan Jaringan Subkutan. Jakarta: Direktorat Jenderal Bina Pelayanan Medik; 2006.
Departemen Kesehatan RI. Mutu dan Cara Uji Sabun Mandi. Jakarta: Direktorat Jenderal Pengawasan Obat dan Makanan; 1996. hlm. 23-25.

Dewan Standarisasi Nasional (DSN) SNI 064085-1996 : Sabun Mandi. Dewan Standarisasi Nasional. Jakarta; 1996. hlm. 2-5.

Kementerian Kesehatan RI. Katalog dalam Terbitan Kementerian Kesehatan Republik Indonesia. Pusat Data dan Informasi Profil Kesehatan Indonesia 2012. Jakarta: Kementerian Kesehatan Republik Indonesia; 2013. hlm. 90.

Poeloengan M. The Effect of Red Ginger (Zingiber officinale Rosc) Extract on The Growth of Mastitis Causing Bacterial Isolates. Indonesian Research Center for Veterinary Science. J. Micro Res. 2011; 5(4):382-389.

Rahmawati M, Aulia AMP, Siti S, Andiriyanto, Soeripto, dan Unang $P$. Bioprospeksi Ekstrak Jahe Gajah Sebagai Anti-CRD: Kajian Aktivitas Antibakteri Terhadap Mycoplasma galliseptikum dan E.coli In-Vitro. Jurnal Ilmu Pertanian Indonesia. Apr; 15(1):7-13.

Roslan AN, Jenny S, dan Anis I. Penurunan Sensitivitas Rasa Manis Akibat Pemakaian Pasta Gigi yang Mengandung Sodium Lauryl Sulphate 5\%. Jurnal PDGI. 2009; 58(2):10-13.

Rowe RC, Paul JS, dan Sian CO. Handbook of Pharmaceutical Excipients. $5^{\text {th }}$ ed. Washington DC: Pharmaceutical Press and American Pharmacist Association; 2006. Hlm. 155, 301, 466, 629, 737. 